\title{
The Pakistan Agricultural Research System: Present Status and Future Agenda
}

\begin{abstract}
JOSEPH G. NAGY and M. A. QUDDUS
Alarming food supply and demand deficits are projected to the year 2020 and beyond for Pakistan, based on its current low investment/low growth agricultural sector. Evidence suggests that agricultural productivity growth and increases in production may not keep pace with past growth rates. Part of the problem is an underfunded and poorly managed agricultural research system that can not hope to contribute significantly to increasing agricultural productivity now or in the future. The World Bank-assisted Agricultural Research II Project (ARP-II) was initiated to partially overcome some of the funding problems and provide institutional development in the areas of organisation, planning, and management of the research system at both the federal and provincial levels. A National Master Agricultural Research Plan (NMARP) was one of the principal goals of the ARP-II as part of improving research planning and management. The objective of this paper is to review the reasons why the Pakistan agricultural research system needs to be revitalised, review the status and problems of the present agricultural research system, and outline a future agenda for Pakistan's agricultural research system based on the plan developed for the NMARP.
\end{abstract}

\section{INTRODUCTION}

At present, Pakistan's agricultural research system is funded, organised and managed at a level where only maintenance research is being achieved with little prospect for a meaningful future increase in crop yields and livestock production through research. The importance of the agriculture sector to Pakistan's economy, the evidence that production and productivity growth are not keeping pace with past growth rates, and the projected widening gap between food and fibre supply and

Joseph G. Nagy is an international consultant based at Saskatoon, Canada. At the time of NMARP preparation, he was the Team Leader/Research Coordinator of the ARP-II (Federal) Hunting Technical Services Ltd. and the technical assistance team at PARC, Islamabad. M. A. Quddus is Deputy Director, Social Sciences Division, Pakistan Agricultural Research Council, Islamabad.

Authors' Note: The authors would like to acknowledge the contributions made by the Chairman, PARC, the coordinators of the priority-setting commodity groups, and the contributing PARC and provincial research scientists. Our gratitude is also extended to Drs Rashed-ul-Qayyum and Ivar Serejski, The World Bank, and to Stan Western of Hunting Technical Services Ltd. However, comments and conclusions drawn from the analysis are the authors' own and may not entirely reflect the views of the Pakistan Agricultural Research Council, the Government of Pakistan, or the World Bank. 
food and fibre demand in the future are very good reasons for revitalising Pakistan's agricultural research system.

As a means of improving research planning and coordination capabilities and revitalising the Pakistan agricultural research system, the Agricultural Research II Project (ARP-II) was launched in 1991 with World Bank assistance (IDA CR. 2154PAK). The preparation of a National Master Agricultural Research Plan (NMARP) was the principal goal of the project. The NMARP, completed in 1997, embodies the Pakistan Agricultural Research Council (PARC) institutional long-term plans along with provincial research master plans (PRMPs) completed by each province.

The purpose of this paper is to: (i) review the reasons why Pakistan's agricultural research systems needs to be revitalised, (ii) review the present status and problems of the Pakistan agricultural research system, and (iii) outline a future agenda for Pakistan's agricultural research system based largely on the findings of the NMARP [PARC (1997)].

Part 2 of the paper briefly reviews the importance of agriculture in the economy of Pakistan and the current trends in agricultural production and productivity growth. Part 3 reviews the present status and problems of the Pakistan agricultural research system in terms of its organisation, management, staffing, and funding. Also reviewed are the past benefits and rates of return from agricultural research in Pakistan. Part 4 presents a future scenario of food supply and demand projections to the year 2020 and the likely benefits from agricultural research based on the present low investment in the agricultural sector and research system. Part 5 prescribes a future agenda for Pakistan's agricultural research system that would enable the system to make the contributions necessary to achieve optimal agricultural production and productivity growth rates.

\section{AGRICULTURE IN PAKISTAN}

\subsection{Agriculture and the Economy of Pakistan}

Agriculture is Pakistan's largest single sector of the economy, ahead of manufacturing, and accounted for 24.8 percent of the total gross domestic product (GDP) in 1995-96. The sector, at present, employs 16.2 million workers, who represent 47.5 percent of Pakistan's total labour force [Pakistan (1996)]. Seventy percent of Pakistan's population (128 million) live in rural areas.

The agriculture sector is an important source of foreign exchange earnings through exports of agricultural commodities and agriculturally-based products. However, substantial foreign exchange is required for imports of agricultural commodities and products. Pakistan's trade balance has been negative for most of its history as a nation. Raw cotton has become Pakistan's largest single agricultural export commodity except in years of depressed cotton production. Raw cotton exports accounted for 7.5 percent of the value of Pakistan's total exports in 1991-92, 
but exports of raw cotton fell to around 1 percent of the value of total exports in 1993-94 and 1994-95, when the crop was affected by the cotton leaf curl virus and inclement weather conditions [Pakistan (1996)]. Exports of rice, the second major agricultural export commodity, accounted for between 3.6 and 6.7 percent of the total value of all export earnings in the period 1988-89 to 1994-95. Fish, fruit, and spices follow as the next highest exported commodities in value terms. Total agricultural commodity exports as a percent of the total value of all Pakistan exports ranged from a high of 31 percent in 1988-89 to a low of 9 percent in 1993-94, indicating the value of a good cotton crop to Pakistan [Pakistan (1996)].

Raw agricultural items such as cotton, wool, and leather products provide the material for many of Pakistan's value-added industries. Goods such as cotton yarn, cotton cloth, carpets, and leather that are manufactured from raw agricultural products, accounted for between 33 and 38 percent of the value of total export earnings in the period 1988-89 to 1994-95 [Pakistan (1996)]. When taken as a total, raw agricultural products plus semi-manufactured agricultural products (i.e., cotton yarn, leather, molasses, animal casings, and tobacco) provided Pakistan between 45 to 55 percent of the value of its foreign exchange earnings in the first half of the 1990s.

Agricultural commodity and product imports contribute substantially to total Pakistan imports and to the negative trade balance. The two major agricultural import categories are the edible oils category and the grains, pulses, and flour category. The value of the former category is made up of about 80 percent palm oil and the remainder is mostly soybean imports. The latter category is made up of over 85 percent wheat imports in any given year. Together, these two import categories represent between 30 and 40 percent of the trade balance deficit in the years 1988-89 to 1994-95. In all, between 13 to 18 percent of the value of total Pakistan imports were agricultural food commodities in the period 1988-89 to 1994-95 [Pakistan (1996)].

\subsection{Agricultural Production and Productivity Growth}

The sources of increased agriculture production and productivity growth in Pakistan have been a more intensive use of land and water resources in combination with new interventions from research. Other significant contributions can be made through an increase in extension, education, training, and investments in rural infrastructure. The agricultural input and product price and trade policy environment can also have a positive or negative effect on production and productivity growth. A review of past production and productivity growth trends can give an indication of the future trend.

Pakistan's average annual growth in overall agricultural production between 1959-60 and 1993-94 has been an impressive 3.2 percent and compares favourably with growth rates of comparable countries [World Bank (1994)]. The overall growth 
rate in agriculture production for the years 1988-89 to 1993-94 was 3.6 percent, which was the same rate of growth for the 1979-80 to 1987-88 period. The growth rate fell to 2.3 percent during the 1969-70 to $1979-80$ period due to several years of severe weather conditions and a cotton virus that depressed production. The growth rate in agricultural production in these three periods lags far behind the 4.9 percent growth rate experienced between 1959-60 and 1969-70. This period marked the beginning of the Green Revolution with the use of high-yielding varieties and the use of increased external inputs such as water and fertiliser [World Bank (1994)]. Thus, the growth rate in agricultural production has slowed, and as indicated by the 196970 to 1979-80 period, can be cut in half by weather and disease.

The growth in agricultural productivity is also important in assessing the direction of future agricultural production. Partial productivity growth rates in terms of kg. per hectare crop yields are presented for selected crops in Table 1 . The longterm growth rate for wheat yield is very modest at 0.8 percent. The growth rate trend of Basmati rice yield, which is a large foreign exchange earner, is negative. The trend in sugarcane yield is also modest at 0.6 percent. Cotton yield has grown steadily at 2.4 percent but has suffered a 2.8 percent decline over the past five years due to adverse weather and disease. However, the crop rebounded with a record of over 9 million bales in 1995-96.

Table 1

Pakistan Area, Production, and Yield Growth Rates of Selected Major Crops (1989-90 to 1993-94 Averages)

\begin{tabular}{|c|c|c|c|c|c|c|}
\hline \multirow[b]{2}{*}{ Commodity } & \multicolumn{2}{|c|}{ Area } & \multicolumn{2}{|c|}{ Production } & \multicolumn{2}{|c|}{ Yield } \\
\hline & $\begin{array}{c}000 ’ \\
\text { Hectares }\end{array}$ & $\begin{array}{l}\text { \% Growth } \\
\text { Rate }\end{array}$ & $\begin{array}{c}\text { 000' } \\
\text { Tonnes }^{\mathrm{a}}\end{array}$ & $\begin{array}{c}\text { \% Growth } \\
\text { Rate }\end{array}$ & Kg./ha ${ }^{a}$ & $\begin{array}{c}\% \text { Growth } \\
\text { Rate }\end{array}$ \\
\hline Wheat & 7,993 & 0.4 & 15,187 & 1.2 & 1,899 & 0.8 \\
\hline Basmati Rice & 1,086 & 1.2 & 1,184 & 0.8 & 1,090 & -0.4 \\
\hline IRRI Rice & 863 & -0.1 & 1,980 & 0.1 & 2,285 & 0.2 \\
\hline Sugarcane & 896 & 0.1 & 37,002 & 0.7 & 42,900 & 0.6 \\
\hline Cotton & 2,748 & 1.0 & 1,636 & 3.4 & 595 & 2.4 \\
\hline Rapeseed & 289 & -1.2 & 215 & -0.5 & 748 & 0.7 \\
\hline
\end{tabular}

Source: Primary data from Agricultural Statistics of Pakistan; Growth rates: Log of 1980-81 to 1993-94 annual data for (1) area, (2) production, and (3) yield, respectively, regressed on Time $(1,2,3 \ldots 14)$. The growth rate is the first derivative of the estimated equation $\times 100$.

The evidence from Table 1 suggests that the partial productivity measures of yield/ha for some major crops have either decreased, plateaued, or are not increasing as fast as in previous periods, particularly in relation to the Green Revolution period. For example, a study of Punjab wheat yields by Byerlee and Siddiq (1990) indicates 
that wheat yields between 1966 and 1976 increased by $59 \mathrm{~kg}$./ha whereas wheat yields rose only by $21 \mathrm{~kg}$./ha in the following ten-year period, suggesting that there is a sustainability problem. Similar comparisons for rice indicate that yields have plateaued and that cotton yields have been increasing at a decreasing rate over the past five years relative to the impressive increase in yields in the 1980 to 1990 period [Further evidence given in Byerlee (1994)].

The above evidence, although not conclusive, points to a potential problem. Pakistan's future agriculture production and productivity increases may not be able to be sustained at the same growth rates as in the past. Increases in production and productivity growth from increased use of land and water (irrigation) along with interventions from research are unable to keep pace with past trends. Most of Pakistan's productive agricultural land is already under cultivation and water resources, and although these could be used more efficiently, these are being used to the near maximum. The agricultural research system, as will be demonstrated in Part 3 and Part 4, can not be expected to provide the same yield-increasing interventions as in the Green Revolution period. Appropriate investments in research, extension, education, and training, including investments in rural infrastructure, are not being made [World Bank (1994)]. Given the low investment in the Pakistan agricultural sector and the slowing production and productivity growth rates, the sector can be characterised as a low-investment/low-growth sector.

\section{PRESENT STATUS OF THE AGRICULTURAL RESEARCH SYSTEM}

\subsection{Organisation, Staffing, and Funding of Agricultural Research}

The publicly funded Pakistan agricultural research system is organised at both the federal and provincial levels. There were 74 research establishments at the federal level, and 106 research institutions at the provincial level in 1990 [Mellor (1994), Vol. II]. Three agricultural universities also conduct research. PARC is the apex body in agricultural research and conducts, promotes, and coordinates research in the country. The research conducted at the federal level has been both applied and adaptive with some long-term priority research. Research is more adaptive with some applied work at the provincial level. There has been a proliferation of research institutes at the both the federal and provincial levels without corresponding increases in trained scientific and management manpower and funding [PARC (1997)].

Management and control of research resources and information throughout the agricultural research system is weak. Programme planning and budgeting (PPB), monitoring and evaluation (M\&E), and management information systems (MIS) are not used effectively or, in most instances, not used at all [World Bank (1990)]. 
Career advancement is largely based on seniority and not on merit although the PARC system is more flexible.

The latest agricultural research manpower survey indicated a total of 4,725 scientists within the Pakistan agricultural research system made up of $455 \mathrm{Ph}$.Ds, 3,006 MScs, and 1,264 B.Scs [Dukesbury (1990]. The proportion of Ph.Ds to total scientific staff in Pakistan, roughly 10 percent, would be considered very low relative to the proportion in developed countries. The latest figures show a ratio of scientists to population in Pakistan in 1988 at 44 per million down from 60 per million in 1973. Comparable international figures indicate that the USA had 2,360 and the UK 1,400 agricultural scientists per million population. Egypt had 300 agricultural scientists per million population which is 6 to 7 times the number in Pakistan [Mellor Associates (1994)]. The number of agro-ecological zones, the various types of agriculture production systems, and a range of 130 commercial crops that the agricultural research system has to support would on its own suggest that there is a requirement for a greater number and for more qualified scientific and support staff.

Expenditure (in current rupees) on agricultural and livestock research was reported to be Rs 742 million in 1988-89. This rose to Rs 1,099 million in the 199293 period, a 48 percent increase [Mellor Associates (1994)]. However, in real terms, when inflation is considered (deflating 1992-93 expenditures by the general consumer price index), the funding levels are about the same. The latest budget allocations for agricultural research in Pakistan for 1996-97 and the current funding environment for agricultural research in Pakistan indicate that it may be difficult to keep future funding levels, in real terms, from decreasing.

Research intensities (research expenditures as a percentage of the value of agricultural production) are an indicator of funding adequacy. The research investment intensity index for Pakistan did increase from 0.0041 ( 0.41 percent) in 1980 to 0.007 (0.7 percent) in 1992 [Mellor Associates (1994), Vol. I, p. 143 from Azam et al. (1991)]. But when compared internationally, the intensity index for newly industrialised Asian countries is 0.015 (1.5 percent), while for all industrialised countries it is 0.018 (1.8 percent), indicating that Pakistan is behind in funding its agricultural research. Agricultural research expenditure as a percentage of agricultural GNP is another indicator of research funding intensity. Pakistan spent 0.02 percent of GNP on agricultural research in 1993 which is far below that of most of other countries.

There is, however, a more serious problem related to research funding. This involves the proportion of overall funding for actual expenditures on research by scientists (operational expenditures), above that for salaries and capital costs. Operational expenditures have been declining as a percentage of overall research expenditures. At AARI, Faisalabad, for example, contingency costs (operational costs plus housing, conveyance charges, medical, and pension) declined from 22.5 percent in 1988-89 to 13.6 percent of all non-development costs in 1992-93, while 
that spent directly on salaries has increased [Mellor Associates (1994), Vol. I, p. 202]. About one-half of the contingency funds are used for research operational costs, leaving about 7 percent for researchers to spend directly on research-related expenditures. There is a consensus that contingency costs should be between 50 and 60 percent, which would leave sufficient funds for research operational costs. This phenomenon of a decreasing trend in operational costs, that are already very low, is widespread throughout the Pakistan research system. Scientists do not have sufficient funds to conduct experiments on-station, and most of them can not leave the research station to conduct on-farm research or to contact farmers and do the farming systems-related research. A continuation of low and declining operational costs will stop all meaningful agricultural research in Pakistan in the not too distant future.

Private sector research, although growing in importance, is very limited at present and has not had a big impact on past production and productivity growth. Multinational companies are working mainly in the seed, pesticide, fertiliser, and tobacco industry, doing adaptive research. The present government stance on privatisation has enticed more national firms into the private research area but problems persist with the uncertainty surrounding privatisation issues and unresolved intellectual property rights regulation and enforcement issues. The public sector will still be asked to fund most of the agricultural research for the near future as the private sector research gains momentum. This is common for countries at Pakistan's stage of development [see Evenson (1998)].

\subsection{Past Benefits and Rates of Return to Research}

Pakistan's agricultural research system has been successful in the past. Several studies have documented the rate of return from past agricultural research in Pakistan. Three separate studies, using slightly different methodologies, research and extension expenditure calculations, and time periods, have documented that the overall internal rate of return from agricultural research ranged between 57 and 65 percent (Table 2). A rate of return of between 57 and 65 percent on research investment is a good return to the tax-payer of Pakistan. This return compares favourably with what would be considered a good return from other public and private investments in Pakistan.

Returns to past crop-specific research investments are also presented in Table 2. The rates of return vary from study to study again because of different methodologies, time periods, and underlying assumptions but the message is clear that the rates of return are substantial. The exception is sugarcane, where no impact from research could be found. This is not an indictment of sugarcane research but is more of an indication of current pricing policies and that sufficient funding and manpower have not been invested in research to reach the threshold necessary to make an impact on the particular problems and constraints found in sugarcane production. The three major crops of wheat, rice, and cotton have impressive returns 
Table 2

Returns from Agricultural Research in Pakistan (Selected Studies)

\begin{tabular}{|c|c|c|c|}
\hline Commodity/Study & Period of Study & $\begin{array}{l}\text { Internal Rate } \\
\text { of Return (\%) }\end{array}$ & $\begin{array}{c}\text { Rupee Return } \\
\text { Eventually } \\
\text { Realised from One } \\
\text { Rupee Invested }\end{array}$ \\
\hline \multicolumn{4}{|l|}{ All Agricultural Research } \\
\hline \multicolumn{4}{|l|}{ Azam et al. (1991) } \\
\hline All Research & 1956-85 & 57 & 10.9 \\
\hline Applied Research & 1956-85 & 82 & 20.9 \\
\hline General Research & 1956-85 & 56 & 10.2 \\
\hline Evenson and Bloom (1991) & 1955-89 & 65 & 9.8 \\
\hline Nagy (1991) & 1960-79 & 64 & 5.0 \\
\hline \multicolumn{4}{|l|}{ Wheat } \\
\hline Azam et al. (1991) & 1956-85 & 76 & 16.5 \\
\hline Byerlee (1993) (Punjab) & 1978-87 & 22 & $\mathrm{NA}^{\mathrm{a}}$ \\
\hline Nagy (1991) & 1964-81 & 58 & NA \\
\hline \multicolumn{4}{|l|}{ Rice } \\
\hline Azam et al. (1991) & 1956-85 & 89 & 24.9 \\
\hline \multicolumn{4}{|l|}{ Iqbal (1991) } \\
\hline Punjab & $1971-88$ & 57 & NA \\
\hline Sindh & 1971-88 & 50 & NA \\
\hline \multicolumn{4}{|l|}{ Cotton } \\
\hline Azam et al. (1991) & 1956-85 & 102 & 43.5 \\
\hline \multicolumn{4}{|l|}{ Iqbal (1991) } \\
\hline Punjab & 1971-88 & 90 & NA \\
\hline Sindh & 1971-88 & 50 & NA \\
\hline \multicolumn{4}{|l|}{ Maize } \\
\hline Azam et al. (1991) & 1956-85 & 46 & 3.8 \\
\hline Nagy (1991) & 1967-81 & 19 & NA \\
\hline \multicolumn{4}{|l|}{ Sugarcane } \\
\hline Azam et al. (1991) & 1956-85 & None & None \\
\hline
\end{tabular}

Source: Nagy and Ali (1996).

aNA indicates 'Not Available'.

to research and high returns from an additional one-rupee investment in research. These crops have benefited from strong varietal improvement research programmes in cooperation with international research centres. In particular, wheat and rice research have benefited from CIMMYT and IRRI involvement and a large proportion of the benefits from research reported in these studies come from the Green Revolution era. 
The rates of return to agricultural research investment in Pakistan reported in Table 2, although substantial, can be misleading. They give the impression that the research system of Pakistan is functioning well. The present funding and manpower situation of the Pakistan agricultural research system, reported previously, should leave no doubt that agricultural research in Pakistan cannot continue to contribute much to increased productivity growth and increased agricultural production. The high rates of return presented in Table 2 are largely from the past glories of the Green Revolution period. The high rates of return are an indication that Pakistan's agricultural research system had done reasonably well in the past and that it can do so in the future, given appropriate funding and manpower levels. Paradoxically, high rates of return in themselves indicate insufficient funding. In the private sector, high rates of return to any enterprise are driven down over time to the average rate of return for the economy. The same should hold true for agricultural research investment. The government should invest in agricultural research at sufficient levels to drive down the rate of return to that approaching the average rate of return in the economy. Thus, the high rates of return for the time-periods depicted in Table 2 indicate that research was a very good investment for Pakistan and that much more should have been invested.

\section{THE FUTURE UNDER A LOW-INVESTMENT/SLOW-GROWTH AGRICULTURAL SECTOR STRATEGY}

\subsection{Food Supply and Demand Projections to 2020}

Three main sources of demand exist for Pakistan's agricultural output in the future. The first source is for food and fibre for Pakistan's population of 128 million which is currently growing at a rate of around 3 percent per annum. The population doubling time is approximately 25 years. This means that Pakistan's population could reach 250 million by the year 2020, and 375 million by the year 2030. The second source of demand is the moderately rising per capita income, which is currently increasing at a real rate of 5 percent per annum [Pakistan (1996)]. Tastes and preferences change with rising incomes, often leading to a greater demand for edible oils and livestock products, in particular milk and poultry. The third source is the demand for exports and the resulting foreign exchange earnings. These three sources of demand will help define future production, demand, and trade of agricultural commodities.

Most food supply and demand projections for Pakistan forecast large agricultural commodity imports in the future if investment in the agricultural sector remains at its current low levels. The International Food Policy Research Institute (IFPRI) projections for food supply and demand and net trade for selected agricultural commodities to the year 2020 are presented in Table 3 [Rosegrant et al. (1995)]. The supply projections take into consideration the effect of future public and 
private sector agricultural research, agricultural extension and farmers' schooling, marketing efficiency, infrastructure, and irrigation. The supply projections in Table 3 are based on a low-investment/slow-growth scenario in the above components. The demand projections are based on current population growth and per capita income growth and projected consumer prices.

With the exception of rice, substantial quantities of all the remaining commodities will have to be imported. Wheat imports would be about 8 times higher, and edible oil imports 13 times higher, than the levels in 1993-94. Wheat imports alone would cost around US\$ 5 billion per year at current prices. This will put an enormous strain on Pakistan's foreign exchange requirements and be an impediment to the future development of the country. Table 3 also presents the production growth rates that the various commodities would have to achieve to satisfy demand in the year 2020. These growth rates are substantial when compared to those in Table 1 and would require an immediate action plan for a highinvestment/high-growth rate strategy to achieve these growth rates.

Table 3

Food Supply and Demand Projections and Net Trade to the Year 2020 (000 Tonnes)

\begin{tabular}{|c|c|c|c|c|c|}
\hline \multirow[b]{3}{*}{ Commodity } & \multirow[b]{3}{*}{ Production } & \multirow[b]{3}{*}{ Demand } & \multirow[b]{3}{*}{ Net Trade } & \multicolumn{2}{|c|}{ Required Growth Rates ${ }^{\mathrm{a}}$} \\
\hline & & & & $\begin{array}{c}\text { To Meet } \\
2020\end{array}$ & $\begin{array}{c}\text { To Meet } \\
2020\end{array}$ \\
\hline & & & & Production & Demand \\
\hline Crops & & & & $(\%)$ & $(\%)$ \\
\hline Wheat & 27,463 & 42,913 & $-15,451$ & 2.3 & 3.8 \\
\hline Rice & 6,207 & 5,309 & 898 & 2.2 & 1.5 \\
\hline Maize & 1,895 & 2,748 & -852 & 1.5 & 2. \\
\hline Other Coarse Grains & 726 & 1,233 & -507 & 1.0 & 2.6 \\
\hline Total Cereals & 36,291 & 52,203 & $-15,912$ & 2.2 & 3.5 \\
\hline Edible Oil & 2 & 1,547 & $-1,545$ & - & 24.5 \\
\hline Roots and Tubers & 1,276 & 1,776 & -499 & 1.9 & 2.9 \\
\hline \multicolumn{6}{|l|}{ Meat and Eggs } \\
\hline Beef (Buffalo) & 764 & 1,109 & -345 & 3.1 & 4.2 \\
\hline Sheep Meat & 1,254 & 1,507 & -253 & 3.6 & 4.3 \\
\hline Poultry Meat & 381 & 679 & -299 & 2.8 & 4.6 \\
\hline Total Meat & 2,399 & 3,295 & -897 & 3.2 & 4.2 \\
\hline Eggs & 669 & 775 & -106 & 4.1 & 4.4 \\
\hline
\end{tabular}




\subsection{Projected Benefits and Rates of Return \\ to Agricultural Research}

Table 4 presents an analysis of the future benefits from conducting research under the present agricultural research system, the low-investment/low-growth scenario as described in Part 3.1. Research and the associated benefits can be divided into two groups: (i) maintenance research-the research and associated funding required to keep yields at their present levels, and (ii) the research and funding associated with increases in yield above maintenance levels. Pakistani research scientists have indicated that at the present level of agricultural research funding and

Table 4

Projected Benefits from Pakistan's Agricultural Research System under a Low-investment/Low-growth Scenario

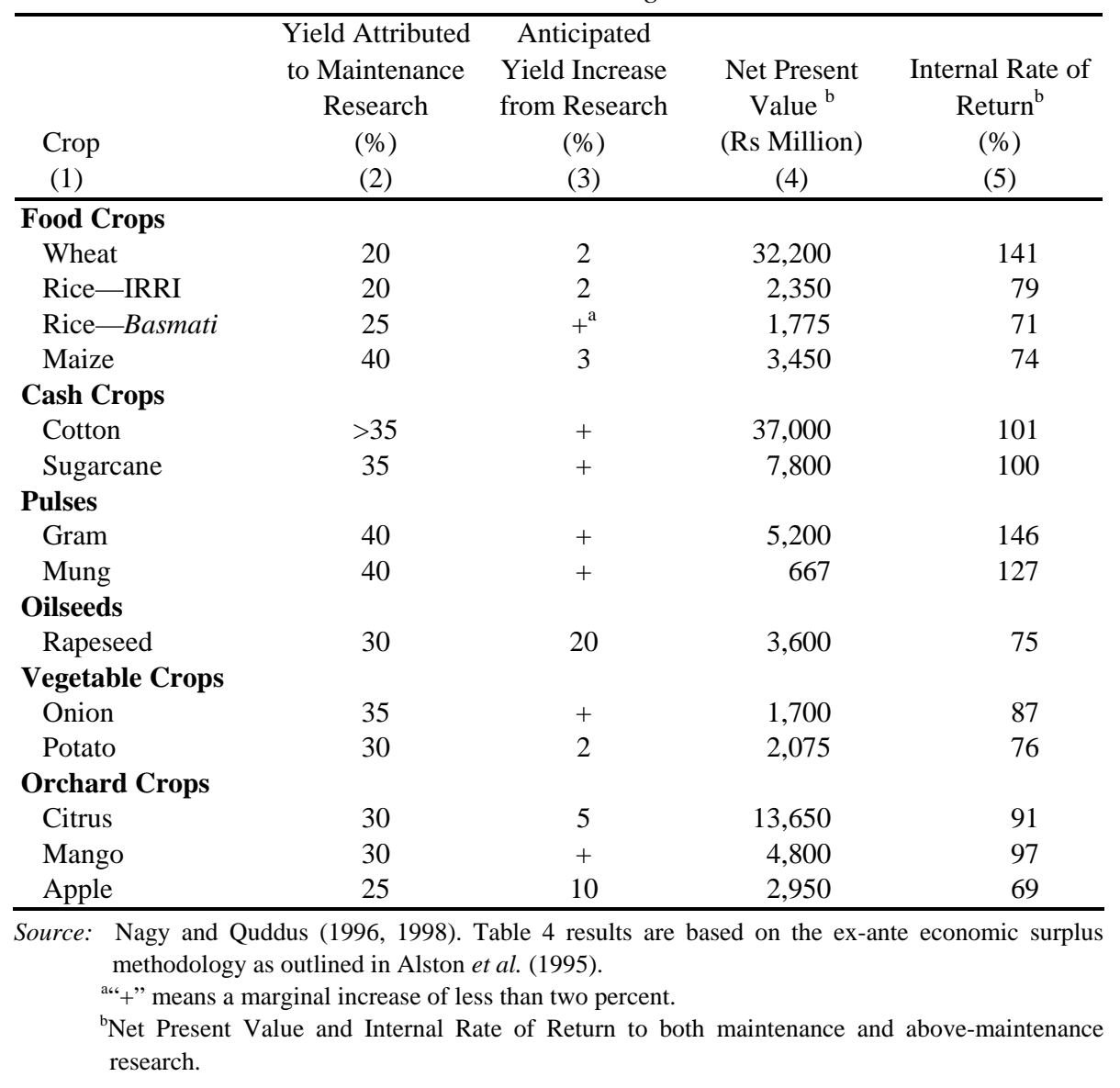


management, crop yields and livestock production can only be held at their maintenance levels with perhaps some marginal increases in crop yield above maintenance levels [Nagy and Quddus (1996, 1998)]. Scientists were asked how much crop yields and livestock production would decrease in 10 to 15 years' time if research was terminated today. The yield gain from maintenance research for each selected commodity is reported in Column 2 of Table 4 as the percentage decrease in yield given that research on the particular commodity is terminated. The figures represent how much yield would drop if there were no research and indicates the benefit from doing maintenance research. The research scientists indicated that under current Pakistan research system funding and management, with the exception of some of the oilseed and orchard crops, the most that can be expected from future crop research is a 1 to 3 percent absolute increase in yield/ha over the next 15 years (Column 3, Table 4). This is far below the yield increases above maintenance yields experienced in the Green Revolution period.

For livestock (buffalo, sheep and goats, cattle), scientists indicated that production would decrease by only 2 percent if research was terminated [Nagy and Quddus $(1996,1998)]$. This is a reflection of the fact that current livestock research is limited and has a minimal effect on productivity. However, scientists indicated that given the current funding and management of livestock research, the overall gains above maintenance research would be virtually zero.

The Net Present Value (NPV) and Internal Rate of Return (IRR) presented in Columns 4 and 5, Table 4 are impressive but one has to realise that most of the research effort is going into maintenance research. The present agricultural research system cannot possibly make a significant contribution to achieving the growth rates required to meet the projected food demand in the year 2020 depicted in Table 3. Had more been invested in agricultural research, the food supply and demand projections presented in Table 3 may not be so alarming. Agricultural research remains a good investment for Pakistan now and in the future. It has been a low-cost source of productivity growth and is one of the key elements to a highinvestment/high-growth strategy for future Pakistan agriculture.

\section{A FUTURE AGENDA FOR PAKISTAN'S AGRICULTURAL RESEARCH SYSTEM}

\subsection{An Agricultural Research System Agenda for the Future}

The National Master Agricultural Research Plan (NMARP) completed in 1996-97 provides intermediate and long-term research and management plans for the years 1996 to 2005 that include: (i) national and provincial commodity research priorities, (ii) national and provincial research institute commodity and crosscommodity priority research programmes and research thrusts, (iii) the means for 
planning, monitoring, and evaluating the agricultural research system through PPB, M\&E, and MIS, (iv) human capital development through long- and short-term training programmes, and (v) human capital investment and recurrent expenditure requirements. The NMARP is summarised in PARC (1997). The detailed management and research plans for each of the provinces, upon which the NMARP is based, are found in the Provincial Research Master Plans (PRMPs) [OPCV/NESPAK (1995, 1995a); Winrock International (1995, 1995a)].

Under ARP-II, technical assistance and funding were made available to PARC and the provinces to undertake work on items (i) to (iv) above of the NMARP strategy. The main points of the strategy are: (i) rationalisation of the number of research institutes, research programmes, and research projects in accordance with national and provincial research priorities as identified in the NMARP, (ii) upgrading management and better organisation of the research system, and (iii) an increase in funding with special attention to the proportions for direct research costs and human and capital investment.

\section{(i) Rationalisation of Research Programmes and Institutes with Research Priorities}

The basis for the research policy and strategy is national and regional (provincial) priority setting. Priorities are set among commodities or commodity groups, production systems, and production factors. These priorities are used to guide resource allocation and the overall level of the national and provincial investment in agricultural research. The research strategy identifies areas of high priority and, over time, guides research resources management to undertake only the priority research. The strategy avoids unnecessary duplication of research efforts amongst the provinces and federal-level research institutions while complementing research in a coordinated fashion. In addition to a mainstream research agenda, federal research institutions should take up research in the national interest that is not undertaken by the provinces. A start to this process has been outlined in the NMARP.

Priority research areas at the national and provincial levels by commodity and commodity group have been identified in the NMARP. The next step is to use the planning and priority setting information to rationalise the number of research programmes along with the number of research institutes (and what each does) according to the level of research effort and funding commitment. At present, the Pakistani research system tries to do research on every possible commodity and research problem area, spreading their limited manpower and funding so thinly that little beneficial research is accomplished. This can be overcome by grouping commodities into three categories based on priorities as follows [adapted from Dey and Norton (1993)]. 
Category I. High Priority: The commodities in the high priority group (those with the highest priority ranking) would receive the most funding and manpower, and would be the core of the research conducted in Pakistan. Research programmes would likely cover a broad spectrum of in-country research on all high and medium priority constraints to increased productivity, with on-station and on-farm farming systems research programmes, and have extensive linkages to international research programmes.

Category II. Medium Priority: A second group would be classified as medium priority, and would receive less funding and financial support than Category I. Research programmes would be focused on the more critical constraints and the research programmes would be more focused, as would linkages to international research programmes.

Category III. Low Priority: The third group classified as low priority would include commodities that might not maintain research programmes but some funds would be used to keep abreast of international research so that full advantage is taken of any opportunity for appropriate technology transfer or new developments in research from other countries.

After identifying the commodities and commodity groups by category, the next step is to carry out a reorganisation of the research and management resources that are in line with the priorities as set out in each category. Present budgets are not sufficient to fund all high, medium, and low priority research. Research managers must shift funds towards the high priority research areas away from low priority and non-productive research. This reorganisation of research resources to high priority research may take several years to complete and may be a painful exercise. However, it is the only way to make the research system more effective at increasing productivity and production.

\section{(ii) Management and Control of Research Resources and Information}

A major objective of the ARP-II project was the establishing of research boards and organisations to oversee the management of research in the provinces. For an integrated approach to research planning in agriculture, livestock, irrigation, fisheries and forestry, and resource allocation, the Punjab Agricultural Research Board (PARB), Balochistan Agricultural Board (BARB), and Sindh Agricultural Research Organisation (SARO) have been constituted/reorganised. In the NWFP, a logical completion of the merger between the provincial research staff and the Agricultural University has yet to be done and must be part of the agenda in the near future. These boards/organisations will now have adequate autonomy to plan, programme, and evaluate research. 
Through the ARP-II project, basic PPB, M\&E, and MIS methodologies and procedures have been developed at the federal level as well as in the provinces. It is essential that those responsible for research management use the PPB system and undertake formal monitoring and evaluation of all projects as a routine process. While staff have been trained in these areas, the next step is to plan a strategy for institutionalising these components and spreading the use of PPB, M\&E, and MIS to all institutes and programmes within a three-to-four-year period. The core groups must now be strengthened in number and with further training. Further training of management staff is also required. Many management staff are not computer-literate or do not have any management training.

A competitive grant system (CGS) of funding has been proposed for allocation of an increasing proportion of development and non-development research funds in future. This system will ensure transparency, efficiency, effectiveness, and competitiveness. A CGS would support the rationalisation of research programmes and institutes as grants would be based on national and provincial research priorities.

\section{(iii) Increase in Funding}

A survey of PARC and provincial scientists and research managers indicated that an optimally funded Pakistan agricultural research system would require funding at five to six times present funding levels [Nagy and Quddus (1996)]. A research system funded at this level would approach international agricultural research standards, one that could deliver significant productivity and production increases. This would bring Pakistan's funding of agricultural research closer to the funding level of 1.5 percent of Agricultural Gross Domestic Product (AGDP) recommended by the National Commission on Agriculture [Pakistan (1988)]. This would enable the agricultural research system to take its part in a high-investment/high-growth agricultural sector strategy.

However, the present national and international climate for funding agricultural research will not entertain increasing agricultural research budgets by five-to-six times the present level. Nor is the Pakistan agricultural research system in a position to accept these higher funding levels. The problems of institution building and institutional strengthening that were to be addressed by ARP-II have still to be fully remedied. It would be pointless to substantially increase funding levels at this time because they can not be used effectively and efficiently.

Having an optimally funded agricultural research system can only be done in stages. It may take the Pakistan agricultural research system between 10 to 15 years or more from now to achieve this. The first step is to identify an immediate agenda that will allow the present research system to become fully effective and efficient using the resources at hand (using the strategy as suggested in (i) and (ii) above). Only then can the next step of implementing a growth strategy be entertained. This 
next step will require increasing the management and research capacity to handle staged funding level increments.

There is also a need to let the country and international donor community know of the long-term strategy for the Pakistan agricultural research system as outlined in the NMARP. Finding the funding will of course be problematic. However, funding may flow easier if the Pakistan agricultural research system can demonstrate that it has its house in order, that it can efficiently and effectively handle increased funding, and that a long-term strategy exists.

\subsection{Future Agenda Benefits and Rates of Return}

Table 5 presents the results from an analysis of the future benefits from conducting research under a high-investment, revitalised agricultural research system which would be the end-result of following the strategy described in Part 5.1. The economic surplus approach was used to identify the NPV and IRR for selected commodities under an optimally funded research system. An optimal funding level is defined as the funding required for the Pakistan agricultural research system (federal and provincial) to significantly increase yields and production of crops and livestock commodities from a research perspective. Sufficient funding would be available to provide an adequate and appropriate mix of staff, equipment, operational costs, buildings, and training costs (without duplication or waste) to undertake prioritised research programmes at the highest level of international standards in accordance with the NMARP. This assumes that the ARP-II institutional strengthening programmes have taken effect and that research would be properly organised and managed, that is, the PPB, M\&E, and MIS programmes are effective and other improvements in research financial management and organisational structure have taken place, including a collegial research environment with recruitment and promotions made on merit.

An optimally-funded research system was determined by the scientists to be five-to-six times the level of funding given to the present research system, although the optimal amount varied from commodity to commodity. For example, wheat researches indicated that an optimal level of funding for them was about six times the present funding level while rice researchers indicated that an optimal funding level was about four times the current levels [see Nagy and Quddus (1996)].

Table 5 presents the estimated NPV and IRR from future agricultural research for the optimal funding scenarios. Each selected commodity is identified with what researchers have projected as the likely increase in yield from doing research under the optimal scenario. Yield increases in Column 2, from research under an optimallyfunding scenario, are much higher than those under the current funding scenario depicted in Table 4 (results from a scenario with yield increases associated with double the current research funding can be found in Nagy and Quddus (1996, 1998). Cotton has the largest NPV from investment in research which represents 
Table 5

Anticipated Benefits and Rates of Return from Pakistan's Agricultural Research System with Optimal Funding and Organisation

\begin{tabular}{|c|c|c|c|c|}
\hline $\begin{array}{l}\text { Crops } \\
\text { (1) }\end{array}$ & $\begin{array}{c}\text { Anticipated } \\
\text { Yield Increase } \\
\text { from Research } \\
(\%)^{\mathrm{a}} \\
(2)\end{array}$ & $\begin{array}{l}\text { Net Present Value } \\
\text { of Research } \\
\text { Benefits } \\
\text { (Rs Million) } \\
\text { (3) }\end{array}$ & $\begin{array}{l}\text { Internal Rate of } \\
\text { Return to } \\
\text { Research } \\
(\%) \\
(4)\end{array}$ & $\begin{array}{c}\text { Efficiency } \\
\text { Index }^{\mathrm{b}} \\
(5)\end{array}$ \\
\hline \multicolumn{5}{|l|}{ Food Crops } \\
\hline Wheat & 35 & 63,900 & 97 & 80 \\
\hline Rice-IRRI & 125 & 13,100 & 85 & 50 \\
\hline Rice-Basmati & 100 & 6,700 & 68 & 26 \\
\hline Maize & 40 & 5,100 & 34 & 15 \\
\hline \multicolumn{5}{|l|}{ Cash Crops } \\
\hline Cotton & 85 & 102,000 & 81 & 46 \\
\hline Sugarcane & 40 & 12,700 & 61 & 20 \\
\hline \multicolumn{5}{|l|}{ Pulses } \\
\hline Gram & 70 & 11,400 & 104 & 71 \\
\hline Mung & 70 & 1,480 & 89 & 62 \\
\hline \multicolumn{5}{|l|}{ Oilseeds } \\
\hline Rapeseed & 100 & 4,500 & 57 & 23 \\
\hline \multicolumn{5}{|l|}{ Vegetable Crops } \\
\hline Onion & 35 & 2,515 & 59 & 22 \\
\hline Potato & 20 & 2,855 & 49 & 11 \\
\hline \multicolumn{5}{|l|}{ Orchard Crops } \\
\hline Citrus & 80 & 34,050 & 74 & 71 \\
\hline Mango & 40 & 8,900 & 58 & 33 \\
\hline Apple & 50 & 5,500 & 52 & 22 \\
\hline
\end{tabular}

Source: Nagy and Quddus (1996, 1998). Table 5 results are based on the ex-ante economic surplus methodology as outlined in Alston et al. (1995).

${ }^{a}$ Includes maintenance research.

${ }^{\mathrm{b}}$ The Efficiency Index is calculated as the NPV of benefits from research divided by the present value of research expenditures for each individual commodity and is a proxy for the marginal rate of return. The higher the Efficiency Index, the greater the return per Rupee invested in research.

substantial returns from research. Wheat is second, and citrus is third. The IRRs shown in Column 4 are also substantial and well above the average rate of return expected in the private sector, and represent a good investment for Pakistan.

Table 5, Column 5 also presents Efficiency Index numbers for selected commodities which can be used to prioritise commodities. The Efficiency Index is calculated as the NPV of research benefits divided by the present value of research expenditures for each individual commodity and is a proxy for the marginal rate of return (the NPV and IRR are average rates of return and, therefore, not as useful as 
efficiency indicators) [see Alston et al. (1996)]. The higher the Efficiency Index, the greater the return per Rupee invested in research. The Efficiency Indexes indicate that wheat, gram, and citrus would certainly be considered as High Priority and placed in Category I as described in Part 5.1. Cotton and IRRI rice would also likely join Category I. Where the two boundaries lie between the three categories is a matter to be discussed among researchers and research managers [see Nagy and Quddus (1996, 1998) and PARC (1997) for a more complete analysis and results of the commodities and their Efficiency Indexes].

\section{CONCLUDING COMMENTS}

To help minimise the potential effects of a widening gap between food supply and food demand, Pakistan requires an optimum high-investment/high-growth strategy for the agriculture sector. Investments need to be made in agricultural research, extension, education, infrastructure, and irrigation with appropriate price, trade, and macroeconomic policies that will give rise to a substantial (but optimal) increase in productivity growth and production. No single element of this strategy can substantially increase productivity and agricultural production alone. But, above all, the Pakistan agricultural research system is a key component of a highinvestment/high-growth strategy. Agricultural research, as it has demonstrated in the past, is the major driving force for increasing agricultural productivity growth and production on a sustained basis.

However, the levelling-off, and in some cases decreasing funding, for the Pakistan agricultural research system in real terms, the low research intensity indicators relative to other developing countries, the low number of scientists per population, the low number of support staff per scientists, the low ratio of scientists with a Ph.D. to other scientists, and insufficient operating funds for researchers to effectively conduct research lead to the conclusion that the agricultural research system can not achieve its mandate now or in the future. Moreover, little benefit from higher funding levels will occur if research management and institutions are not strengthened to use higher funding levels efficiently.

The future agenda to revitalise agricultural research outline in Part 5 can be accomplished only if the task of organising the administration of research under the newly created institutions of PARB, SARO, and BARB is completed and the suggested changes under ARP-II for PARC and the NWFP are implemented. Institutionalisation must continue to the point where these institutions are fully functional and autonomous. Although the ARP-II project laid down a strong base to further strengthen the major management and research components of the agricultural research system, much still remains to be done to capitalise on the ARPII effort.

The Planning Division, Finance Division, Government of Pakistan, and the provincial Finance and Planning Departments should adopt the NMARP once it is 
approved by the Government of Pakistan as the guiding document for the allocation of resources to agricultural research. The provincial research organisations at the federal level and the Boards and Organisations in the provinces should immediately initiate the shifting of funding and manpower resources towards priority research programmes/projects. Once the NMARP and PRMPs are approved, a standing Task Force/Steering Committee headed by the Chairman, PARC with DGs./Chief Executives of the provinces should be formed to oversee the implementation of the plans.

Once the NMARP is approved, it and the PRMP's must be sold at the national, provincial, and international levels. The Government of Pakistan, provincial governments, and international donor agencies must be informed about the future and immediate research agendas of the Pakistan agricultural research system.

However, at the time of publication of this article, no commitment has been made by PARC and the provincial research organisations or by the Government of Pakistan to adopt and implement any part of the NMARP. Nor has any donor agency expressed an interest. At present, the Pakistan agricultural research system is much the same as described in Part 3 of this paper.

\section{REFERENCES}

Alston, J. M., G. W. Norton, and P. G. Pardey (1995) Science under Scarcity: Principles and Practice for Agricultural Research Evaluation and Priority Setting. Ithaca, NY: Cornell University Press.

Azam, Q. T., E. A. Bloom, and R. E. Evenson (1991) Agricultural Research Productivity in Pakistan. Pakistan Agricultural Research Council, Islamabad.

Byerlee, D. (1993) Technical Change and Returns to Wheat Breeding Research in Pakistan's Punjab in the Post-green Revolution Period. The Pakistan Development Review 32:1 69-86.

Byerlee, D. (1994) Agricultural Productivity in Pakistan: Problems and Potential. Prepared for World Bank Agricultural Sector Review, World Bank, Washington, D.C.

Byerlee, D., and A. Siddiq (1990) Sources of Growth in Wheat Yields in Pakistan's Punjab, 1965-2000: Is There a Sustainability Issue? CIMMYT Economics Working Paper 90/04. CIMMYT, Mexico.

Dey, M. M., and G. W. Norton (1993) Analysis of Agricultural Research Priorities in Bangladesh. International Service for National Agricultural Research. The Hague, The Netherlands. (ISNAR Discussion Paper No. 93-07.)

Dukesbury, J. M. (1990) Agricultural Research Institutions in Pakistan. Winrock International and Pakistan Agricultural Research Council, Islamabad.

Evenson, R. E. (1998) The Economics of Intellectual Property Rights for Agricultural Technology. Conference on Intellectual Property Rights for Plant Genetic Resources, University of Rome, Tor Vergata (June 1-2). 
Evenson, R. E., and E. A. Bloom (1991) Research and Productivity in Pakistan Agriculture. In A. S. Haider, Z. Hussain, R. McConnen, and S. J. Malik (eds) Agricultural Strategies in the 1990's: Issues and Policies. Islamabad: Pakistan Association of Agricultural Social Scientists.

Iqbal, M. (1991) Rates of Return to Investment in Agricultural Research. The Case of Rice and Cotton in Pakistan. Unpublished Ph.D. thesis, Department of Agricultural Economics and Rural Sociology, The Ohio State University.

Mellor Associates (1994) Institutional Reforms to Accelerate Irrigated Agriculture Volumes I and II., Washington, D.C.

Nagy J. G., and M. A. Quddus (1998) National Agricultural Commodity Research Priorities for Pakistan. Agricultural Economics 19: 327-340.

Nagy, J. G. (1991) Returns from Agricultural Research and Extension in Wheat and Maize in Pakistan. In Evenson and Pray (eds) Research and Productivity in Asian Agriculture. Ithaca, New York: Cornell University Press.

Nagy, J. G., and M. M. Ali (1996) PARC Social Science Division Planning Report Agricultural Research Project II, Hunting Technical Services Ltd. and Pakistan Agricultural Research Council, Islamabad. (Report No. ARP-II(Federal)-1996-4.)

Nagy, J. G., and M. Quddus (1996) National Level Agricultrual Commodity Research Priorities for Pakistan. Agricultural Research Project II, Hunting Technical Services Ltd. and Pakistan Agricultural Research Council, Islamabad. (Report No ARP-II(Federal)1996-6.)

OPCV/NESPAK (1995) NWFP Research Master Plan, Agricultural Research Project-II (IDA CR 2154-PAK), Overseas Project Corporation of Victoria, Government of NWFP, and University of Peshawar.

OPCV/NESPAK (1995a) Punjab Research Master Plan, Agricultural Research Project-II (IDA CR 2154-PAK), Overseas Project Corporation of Victoria, and Government of the Punjab Agricultural Department.

Pakistan, Government of (1988) Report on the National Commission on Agriculture. National Commission on Agriculture, Ministry of Food and Agriculture.

Pakistan, Government of (1996) Economic Survey. Finance Division, Economic Adviser's Wing, Islamabad.

Pakistan, Government of (Various Issues) Agricultural Statistics of Pakistan. Ministry of Food, Agriculture and Cooperatives, Food and Agriculture Division, Economic Wing, Islamabad.

PARC (1997) National Master Agricultural Research Plan. Pakistan Agricultural Research Council, Ministry for Food and Agriculture, Islamabad, Pakistan.

Rosegrant, M. W., M. Agcaoili, and N. D. Perez (1995) Global Food Projections to 2020 Implications for Investment. International Food Policy Research Institute. Washington, D.C. (Food, Agriculture, and the Environment Discussion Paper No. 5.)

Winrock International (1995) Sindh Provincial Agricultural Research Plan. Agricultural Research Project II. (IDA CR 2154-PAK). 
Winrock International (1995a) Balochistan Provincial Agricultural Research Plan. Agricultural Research Project-II. (IDA CR 2154-PAK).

World Bank (1990) Staff Appraisal Report, Pakistan: Agricultural Research II Project. Agriculture Operations Division, Country Department I, Europe, Middle East and North Africa Region. (Report No. 7614-PAK.)

World Bank (1994) Pakistan: A Strategy for Sustainable Agriculture Growth Agricultural Operations Division, South Asia Region. (Report No. 13092-PAK.) 